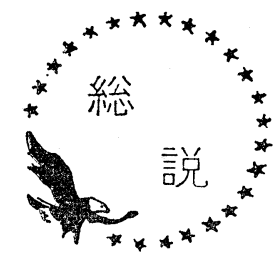

I. まえがき

工業用潤滑剂には, タービン油, ベアリング油, ギ ヤ一油, 油圧作動油, コンプレッサー油, 摺動面潤滑 油, グリ一ス掠よび金属加工油 (切削油, 圧延油など) など，内燃機関に使用するいわゆるエンジン油以外の 油が包含される。

これらの油に使用する添加㓮も目的に応して数多く あり，限られた紙数でこれらをすべて紹介することも できないので,これらの添加剤のらち主なもの，すなわ ち油性剤, 極圧添加剤, 少ビ止め剤などを主として紹介 する。このほか粘度指数向上剂, 流動点降下剂, 酸化 防止剤，あわ立ち防止剤なども多く使用されているが， これらは別項で紹介されるので, 本稿では除いた。

\section{II . 油 性 向上剂}

金属 2 面が接触しながら摩擦すると摩擦条件によつ ては摩擦面の温度は異常に上昇する。たと光ば Bowden, Tabor1) などの測定結果では，鋼面上をコンス タンタンの丸棒をすべらせたときに，500 cm/ $/ \mathrm{sec} 100$ $\mathrm{g}$ で $470^{\circ} \mathrm{C}$, 鉛, ウッドメタル, ガリウムなどをす心゙ うせたとさには，それぞれの金属の融点にまで達する ことを認めている。潤滑剤を使用したときには，潤滑 剤掠よび金属部分を媒介して，この熱忟放散するが， このために潤滑剤の温度は異常に高くなる。たとえば 山岳地带を走る重量トラックの朄車ケース内の温度は 90〜130 ${ }^{\circ} \mathrm{C}$ になることは珍しくない。このような状態

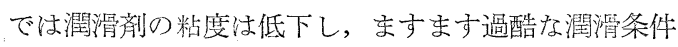
となる。

第 1 図に摩擦係数と $Z N / P$ との関係を示した。 $Z$ は潤滑油の粘度， $N$ は軸回転数， $P$ は荷重である。 完全潤滑状態すなわち $Z N / P$ が大きいときには摩擦 2 面間には相当に厚い潤滑油の層が形成され，金属面 の接触はほとんど抗こらない。したがつて摩擦係数は 低く, 温度の上昇も少ない。ところが境界潤滑领域す なわち $Z N / P$ が小さくなると摩擦面間の潤滑油膜は きわめてらすくなり金属面同志の接触が起るので摩擦 係数は增大しゴーリング, スコーリング，焼付きなど

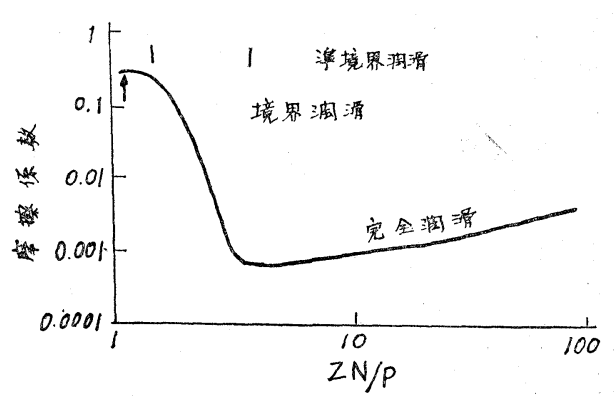

第1図 潤滑の種類

種々の摩擦面の損傷が起る。

このような現象を防止するには, 種々の添加剤を潤 滑油中に加えるが，これが油性向上纱 (Oiliness improver) 極圧添加剤 (Extreme pressure agent) 摩耗 防止剂 (Antiwear agent)である。

油性剤として使用されるのは, 炭素数 10２0の高 分子の直鎖脂肪酸, 直鎖アルコール, エステル，金属 セッケン,アミン，ケトンなど，分子端に極性基をも ち，分子構造が比較的長い形をしている化合物であ る。

これらは配列のよい吸着膜を作り，長い分子鎖間の 相互引力で吸着膜を強固にしている。（第2図）

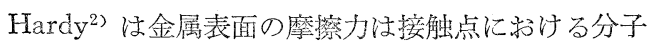
閒引力に関倸すると考元, 表面に脂肪酸の吸着層が形

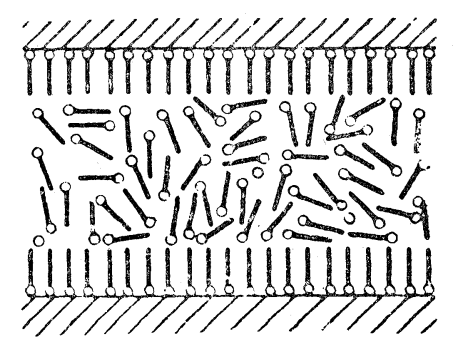

第 2 図 油性剂による吸着層の生成 
成されたときには，この引力が抢扔われて摩擦が減少 するといつている。したがつて金属 2 面の接触は脂肪 酸の炭化水素鎖の摩擦におきかわるわけであり,また 摩擦の減少の程度以吸着層の下にある金属面間の分子 間引力を抢扮う程度によりきまり, これは添加剤分子 の極性と炭化水素鎖の長さによつてきまる。

また一方 Bowden ${ }^{3)}$ は，摩擦は金属表面の凸部分 が接触することにより融着したりひき離されたりする ことからおこる。摩擦を減少するためには金属部分を 強、吸着膜でおお打つて金属接触の機会を少なくすれば よいと考えている。

油性剤を使用したときにもつとも問題になるのは， 高温において效果を失ならことであり，その温度が油 性㓮一金属の組合わせにより異なる。第 3 図に種々の 金属面に種々の油性郕を使い, 温度を変えて摩擦した ときの摩擦你数を示した。始めに温度を上げても摩擦 係数はほとんど変化しないが，ある温度になつたとき に摩擦が急激に上昇している。この温度が金属と油性

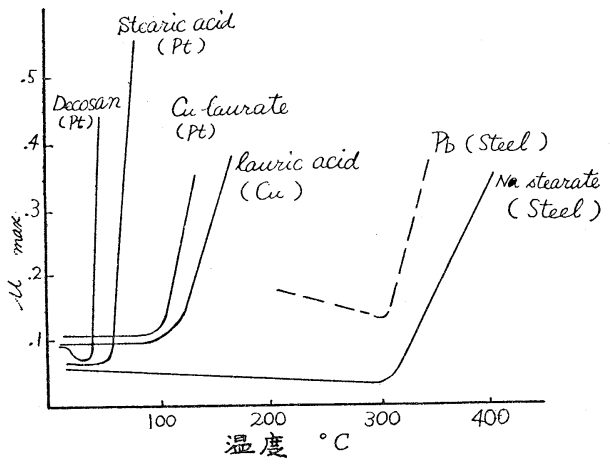

第 3 図 潤滑表面の摩擦係数に対す る温度の影響

剂の種類により異なつている。

たとえば炭化水素であるデコサン (融点 $\left.44^{\circ} \mathrm{C}\right)$ は白 金上で約 $45^{\circ} \mathrm{C}$ ，ステアリン酸（融点 $69^{\circ} \mathrm{C}$ ) は白金上で 約 $70^{\circ} \mathrm{C}$ で油膜が破断しているのに，ラウリン酸（融 $44^{\circ} \mathrm{C}$ ) 点で銅板上で摩擦したときにはラウリン酸銅の 融点にほぼ近い $110^{\circ} \mathrm{C}$ まで摩擦係数の変化がない。

このように炭化水素, アルコールなどを油性剤とし て使用したときには，便用した油性剤の融点付近の温 度で摩擦係数が急上昇し油膜が破断するが，脂肪酸を 鉄，銅などの金属面の摩擦に使用すると，脂肪酸の融 点以上の温度になつても摩擦は変らず，脂肪酸の金属 塩の融点付近で始めて急上昇している。すなわち炭化
水素,アルコールなどは金属面に物理吸着しているだ けであるが，後者の場合には油性剂と金属面の間で化 学反応が起り，いわゆる化学吸着していることを示し ている。第 4 図に脂肪酸の炭素数を変えたときの油膜 の破断温度 (転移温度) との関係を示した ${ }^{1)}$ 。

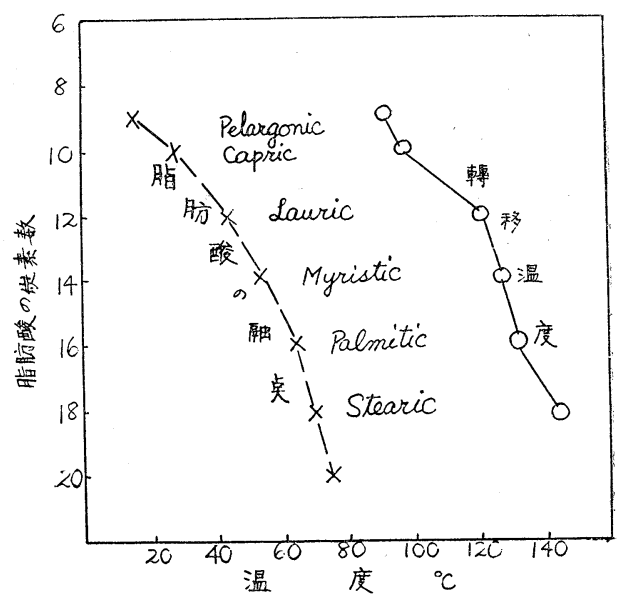

第 4図 脂肪酸鎖数と䎐移温度 (鋼)

しかし化学吸着したとしても, 摩擦面が温度上昇し て $120 \sim 130^{\circ} \mathrm{C}$ 以上になれば脱着してしまうので, 油 性剤は高温の部分では使えない。

金属セッケンも油性剤として使用することが多い。 金属セッケンは鉄表面と反応して鉄セッケンを生成す るといわれる20)。

各種金属セッケンの耐摩擦性と耐荷重性を第 1 表 ${ }^{21}$ に示した。

実際の潤滑油に油性剤を使用する場合に，どのよう な構造の化合物をどのくらい使用するかは，潤滑条件 使用条件などによつて異なり，その選定はなかなか複 雑である。

たとえば鉄の圧延には脂肪酸またはそのグリセライ ドがよく使用されるが，銅，アルミニウムなどの圧延 には使用できない。これは圧延性はよいが，焼鏠した ときのステインの問題があり，高級アルコールがよく 使用されるよらである。

油性剤の吸着膜が破れるとスティックースリップ現 象があらわれる。これのもつとも敏感なのは大型工作 機械の瀷動面の潤滑油である。スティックースリップ 防止のためにはスティックースリップ試験において静 止摩擦係数と運動摩擦係数との比（付着一すべり比）

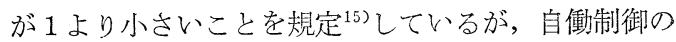




\section{第 1 表 金属セッケンの耐荷重性}

\begin{tabular}{|c|c|c|c|}
\hline 金属セッケン & $\begin{array}{l}\text { 添 加 量 } \\
\text { 単位 }\end{array}$ & $\begin{array}{c}\text { 耐摩耗性 } \\
\mathrm{kg} / \mathrm{mm}\end{array}$ & $\begin{array}{c}\text { 耐荷重性 } \\
\mathrm{kg}\end{array}$ \\
\hline ステアリン酸 $\mathrm{Na}$ & 1 & 20 & 120 \\
\hline パルミチン酸 $\mathrm{Na}$ & 1 & 18 & 120 \\
\hline オレイン酸 $\mathrm{Na}$ & 1 & 18 & 120 \\
\hline ステアリン酸 $\mathrm{Ca}$ & 1 & 22 & 140 \\
\hline オレイン酸 $\mathrm{Ca}$ & 1 & 24 & 140 \\
\hline ステアリン酸 $\mathrm{Mg}$ & 1 & 20 & 120 \\
\hline オレイン酸 $\mathrm{Mg}$ & 2.5 & 22 & 120 \\
\hline ステアリン酸 $\mathrm{Al}$ & 5.0 & 18 & 140 \\
\hline パルミチン酸 $\mathrm{Al}$ & 5.0 & 20 & 140 \\
\hline オレイン酸 $\mathrm{Al}$ & 5.0 & 92 & 160 \\
\hline ステアリン酸 Zn & 5.0 & 92 & 160 \\
\hline パルミチン酸 $\mathrm{Zn}$ & 5.0 & 86 & 160 \\
\hline オレイン酸 $\mathrm{Zn}$ & 5.0 & 120 & 160 \\
\hline ステアリン酸 Co & 5.0 & 72 & 160 \\
\hline ステアリン酸 $\mathrm{Mn}$ & 5.0 & 84 & 160 \\
\hline ステアリン酸 $\mathrm{Fe}$ & 5.0 & 94 & 160 \\
\hline オレイン酸 $\mathrm{Fe}$ & 5.0 & 90 & 160 \\
\hline ステアリン酸 Sn & 5.0 & 100 & 200 \\
\hline オレイン酸 Sn & 5.0 & 110 & 200 \\
\hline ステアリン酸 $\mathrm{Cu}$ & 5.0 & 160 & 200 \\
\hline パルミチン酸 Cu & 5.0 & 220 & 200 \\
\hline オレイン酸 $\mathrm{Cu}$ & 5.0 & 200 & 200 \\
\hline ステアリン酸 $\mathrm{Pb}$ & 5.0 & 290 & 200 \\
\hline $\begin{array}{l}\text { オレイン酸 } \mathrm{Pb} \\
\text { (シェル } 4 \text { 球試䮖 }\end{array}$ & 5.0 & 280 & 200 \\
\hline
\end{tabular}

位置ぎめのような比較的高速の精密作業では，付着一 すべり比が 0.8 くらいが必要といわれている ${ }^{16) 。 ~}$

Merchant ${ }^{17)}$ 注種々の化合物を使用して静止摩擦係 数と動摩擦係数を測定している。1例を第 5 図に示し た。

\section{III. 極圧添加剂}

実際の機械装置の中には摩擦面の温度上昇が大で, 油性剂では脱着して効果のないものが多くある。たと えば自動車，圧延機などの高荷重紫車および軸受，重 切削などの金属加工などである。このような装置では 高温においてもなお摩擦を減少し, かつ燒付きを防止 できる潤滑剤が必要である。このために生れたのが極 圧添加剂である。

極圧添加鼡として使用されるのは，塩素，イオウ， リンを含む化合物（主として有機化合物）であり，通 常の場合, これらの化合物を使用目的に応じて適当に

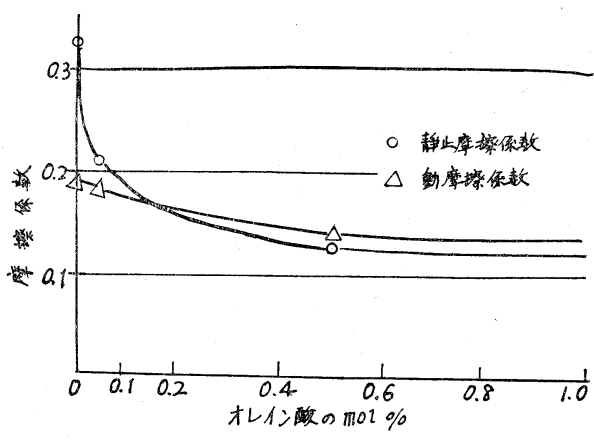

\section{第 5 図 オレイン酸の添加量と 摩擦係数との関係}

組合わせて使用する。

塩素化合物としては塩素化パラフィン（塩素20７0 \%), 塩素化ナフタリン, メチルトリクロロステアレー ト，トリクロロレゾルチノール，イオウ化合物として ジベンジルジサルファイド, 不飽和化合物の硫化物, ジアルキルザンチルエーテル, リン系化合物としてト リブチルホスファイトのような亜リン酸エステル， トリクレジルホスフェートのようなリン酸エステルな ぞが代表的なものである。しかし実際に使用するの は，イオウ，塩素，リンを同時に含む化合物が多く， たとえば動植物油脂に塩化イオウを反応させたもの， 塩素とイオウを含むクロロベンジルアルキルザンテー 卜，不飽和化合物または高級脂肪族アルコールと硫化 リンとの反応物などが使用され，特許も無数に提出さ れている。

極圧添加剤の效果はこれらの化合物が金属面と反応 して金属塩化物，金属硫化物，金属リン化物なぞを生 成するためと考光られている。

金属表面に生成したこれらの化合物の薄膜は, 融点 が低く，せ九断強さが小さいので，地肌の金属よりも 摩擦係数が低く, ちようど鉄の表面にホワイトメタル などの軟質金属の薄膜を張つて潤滑作用を営なませた のと同様の効果が期待できる。したがつて極圧添加郕 として有効なのは，極圧条件に扔いて金属同志の接触 部分の高温部分と反応して金属塩を生成し，かつこれ らの表面膜が軟質で潤滑性をもつことが必要である。

塩素，イオウ化合物を使用したときに，摩擦表面に 生成するのは，それぞれの金属塩化物，金属硫化物で あるが，生成した表面膜の性質は第 2 表の上うに異な つている。

塩化物の特長は摩擦係数の低いことであるが, これ 


\section{第 2 表 表面膜 の 性 質}

薄膜 潤滑に必 摩擦係数要な厚さ 薄膜の性質

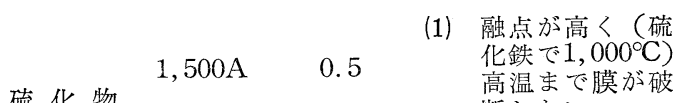

硫 化 物

以上

塩 化 物

以上 $<ら \checkmark$

(2) 水に対して安定 である。

(1) 融点が低く $\left(\mathrm{FeCl}_{2}\right.$ で約 600 ${ }^{\circ} \mathrm{C}, \mathrm{FeCl}_{3}$ で約 $\left.300^{\circ} \mathrm{C}\right)$, 比較的 低温で破断す
$1,000 \mathrm{~A} \quad 0.2$ る。

（2）水と合つて加水 分解する。

はグラファイト, 二硫化モリブデンと同様に層状構造 を有するためといわれる。したがつて摩擦を減少する といら点からはもつともすぐれているが，300～400 で膜が破断し，また水に合うと加水分解して潤滑性を 失ならとともに，生成する塩酸が腐食性を示す欠点が ある。これに反して硫化物の膜は塩化物膜よりも摩擦 係数が高く, 0.5 前後よりも小さくならない。原因は 恐らく膜の構造が異なるためであろら。しかし鉄その 他の金属の硫化物膜は安定で，水にも熱にも強いのが 特長である。

潤滑に必要な硫化膜の最小厚さは，鋼面上に種々の 厚さの硫化膜を作り，摩擦係数を測定して求めている

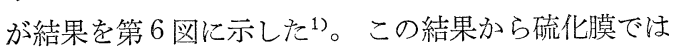
$1,500 \AA$ 以上になると摩擦係数が低下することがわか る。

極圧添加剤が金属面と作用して硫化金属膜などを生 成することにより焼付さを防止するといら米英の人達 の考光方に対し, Rebinder ${ }^{4) 5)}$ などのソ連の人達は,

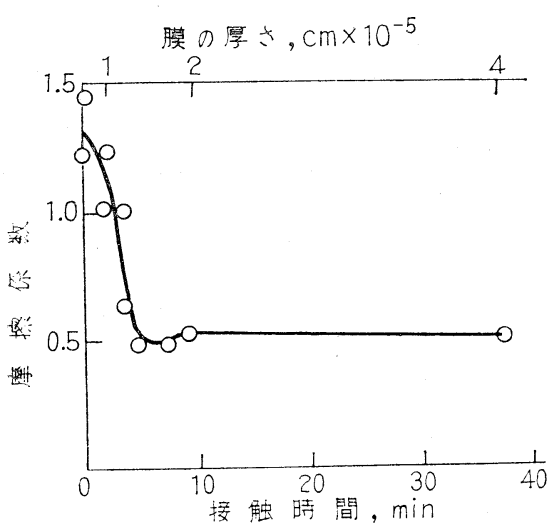

第 6 図 金属硫化物の厚さと摩擦係数
四塩化炭素のような塩素化合物を切削に使用したとき に, 切削時において試料片の微小割れ目のなかに物理 吸着し，金属の可塑性を減少させるといつている。

イオウ化合物, 塩素化合物などが常温で金属面と反 応すれば，いわゆる腐食現象で好ましくない。といつ て金属面同志の直接接触が起り始めたような事態でな お反応が起らないようでは，その化合物は極圧添加剂 として使用できない。

各種イオウ化合物を基油に一定量溶解し, 鉄粉と種 々の温度で反応させて鉄粉上に生成した硫化鉄を定量

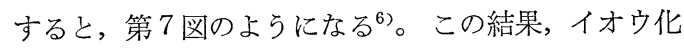
合物の型によつて鉄粉との反応が大きくなる温度が異 なることがわかる。すなわち，硫化テルペンは $150^{\circ} \mathrm{C}$, ナフチルメチレンチオール, ジベンジルジサルファイ ドは $200^{\circ} \mathrm{C}$ 以下ではほとんど硫化鉄を生成しないが， これ以上の温度になると急激に生成量が大になり, 硫 化大豆油, Zn ジチオホスフェートは $200^{\circ} \mathrm{C}$ 以上にな つても生成量はそれほど増加していない。またセチル メルカプタンなどは高温になつても金属面とほとんど 反応しない。

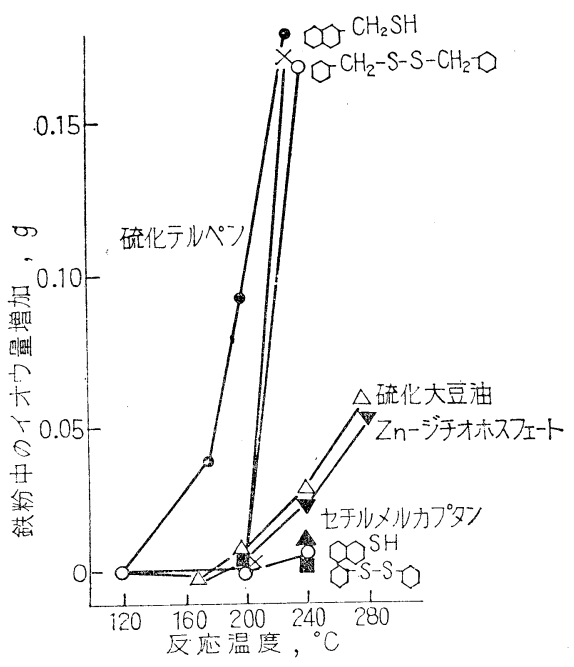

\section{第7図 反応温度を変えて鉄衡とイオウ 化合物とを反応させたときに， 鉄粉と反応したイオウ量}

実用面では反応性の異なつたこれらの化合物を使用 条件に合わせて使いわけている。たとえば自動車で新 しい霜車を組立てたときに，荬面になじみを与えるた めに，活性の大きいイオウと鉛セッケンとを組合わせ て使用し，また走行速度の大きい乘用車と負荷の大き いトラックとでは，個々の化合物で性能が異なるの 
で，使いわけたり，また組合わせたりして使用する。 (第 3 表 ${ }^{7}$ )

\section{第 3 表 種々の化合物の実用性能}

\begin{tabular}{|c|c|c|}
\hline 添加剤名 & 高速試験 & 高荷重試息 \\
\hline 塩 素 化 合 物 & + & $0 \sim(+)$ \\
\hline $\begin{aligned} \text { 活性イオウ } & \text { (非カーボ } \\
& \text { キシル化合物) }\end{aligned}$ & + & - \\
\hline $\begin{array}{l}\text { かなり不活性なイオウ } \\
\text { (非カーボキシル化合物) }\end{array}$ & + & $(-)$ \\
\hline $\begin{array}{l}\text { かなり不活性なイオウ } \\
\text { (カーボキシル化合物) }\end{array}$ & $(-) \sim(+)$ & + \\
\hline $\begin{array}{l}\text { 相当に不活性なイオウ } \\
\text { (カーボキシル化合物) }\end{array}$ & + & + \\
\hline カーボキシルエステル & - & + \\
\hline カーボキシル酸 & $(-) \sim-$ & + \\
\hline $\begin{aligned} \text { オキシホスファイト酸 } \\
\text { エステル }\end{aligned}$ & + & + \\
\hline $\begin{aligned} \text { オキシホスファイト } \\
\text { 中性エステル }\end{aligned}$ & 0 & 0 \\
\hline $\begin{aligned} \text { オキシホスフェイト } \\
\text { 中性エステル }\end{aligned}$ & 0 & 0 \\
\hline 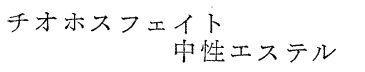 & + & + \\
\hline $\begin{array}{l}\text { 十全く有効 }(+) \text { わずか } \\
\text { に有害 } 0 \text { 効果なし, し } \\
\text { 有害 }\end{array}$ & $\begin{array}{l}\text { に有効 (- } \\
\text { 加乙無害 }\end{array}$ & $\begin{array}{l}\text { わずか } \\
\text { 完全に }\end{array}$ \\
\hline
\end{tabular}

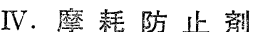

リン化合物は特に摩耕防止剂として有効である。こ れはリン化合物が金属面と反応してリン化鉃を生成し これが鉄と混合してかなり熔融しやすい合金が鉄表面 に生成し，摩擦表面を平滑にしていると考えられてい $b^{8)}$ 。

代表的な摩耗防止剤であるトリクレジルホスフェー トは，第 8 眓に示すように $200^{\circ} \mathrm{C}$ では鉄とほとんど反 応しなが， $270^{\circ} \mathrm{C}$ になるとよく反応方る。摩擦金属 面は平滑に磨いてはあるが，微視的には四凸の大きい ものである。したがつて摩擦二面が接触したときには 凸部同志のみが接触することになる。このために全荷 重を凸部のみで受けるので，凸部に晾ける荷重はきわ めて大きくなり，発生する熱も大きい。リン化合物は 摩擦面の凸部で僢間的に発生した高温部分にのみ反応 してリン化鉄を生成する。しかし凹部分は接触してい ないので温度が低く，反応はほとんど起らない。この リン化鉄はさらに鉄と合金を作り，鉄よりも融点が $500^{\circ} \mathrm{C}$ も低くなる（第 4 表）ので，凸部注融解して凹 部に流しこまれる。この結果, 摩擦表面の凸部分はだ

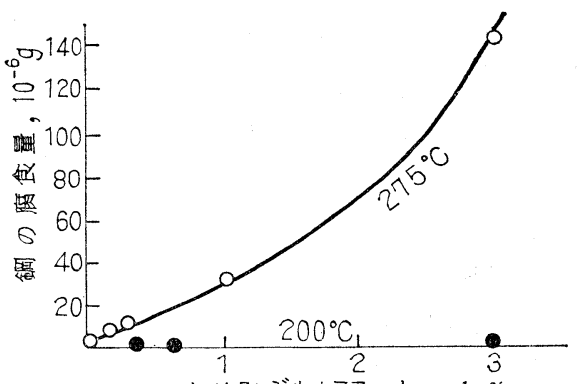

トリフレジルホスフェート wt \%

第 8 図 トリクレジルホスフェート と鋼との反応

第 4 表 合金の融点

\begin{tabular}{lr}
\multicolumn{1}{c}{ 合 } & 融 ${ }^{\text {点 }}{ }^{\circ} \mathrm{C}$ \\
Fe & 1,525 \\
Fe-Fep (P 10.2\%) & 1,000 \\
$86.5 \mathrm{Fe}-10 \mathrm{P}-3.5 \mathrm{C}$ & 952 \\
$15 \mathrm{Fe}-85 \mathrm{FeS}$ & 985 \\
$30 \mathrm{~Pb}-70 \mathrm{FeS}$ & 1,000 \\
$73 \mathrm{PbS}-27 \mathrm{FeS}$ & 869 \\
$\mathrm{Cu}$ & 1,083 \\
$8.27 \mathrm{P}-\mathrm{Cu}$ & 707
\end{tabular}

んだしなくなつて部分的に高荷重の部分がなくなり， したがつて焼付きの原因となる高熱の発生もなくな る。一種の研磨作用が行なわれるわけで，このような リン化合物の作用を“Chemical polishing action” と よんでいる。

リン化合物の摩耗防止作用には最適添加量があり, 多く入れすぎると效果が失なわれる。（第9図）

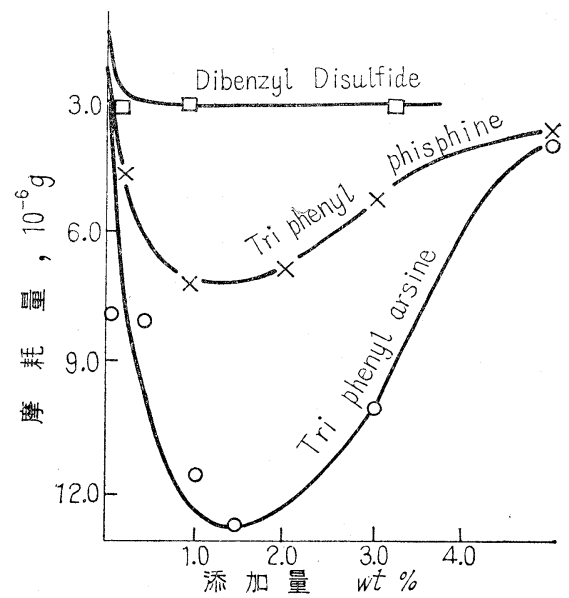

第 9 図 リン化合物の添加量と摩耗量との関係 
また Barcroft ${ }^{8)}$ はトリクレジルホスフェートとス テンレス鋼との反応速度を求めているが，第10図に示 すようにばらついている。この原因怯鋼面上に生成し た $\mathrm{Fe}_{2} \mathrm{P}$ の非常にうすい膜 (500 ̊ またはそれ以下)

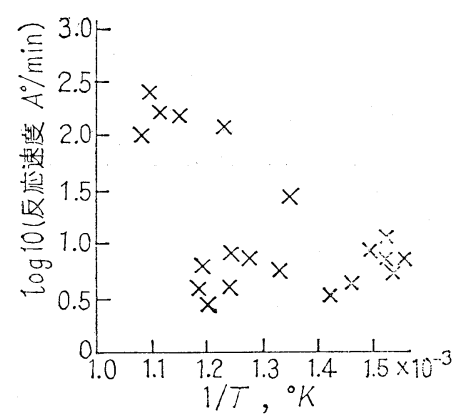

\section{第10図 トリクレジルホスフェートとス テンレス鋼との反応}

(0.5 wt \% p. 流動パラフィン溶液)
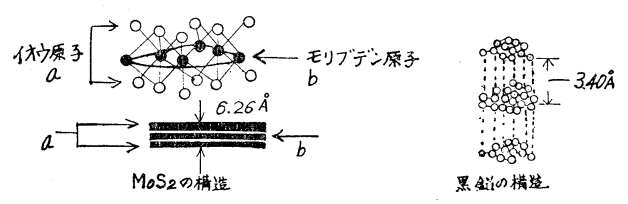

第11図 $\mathbf{M o S}_{2}$, 黒鉛の構造

が鉄原子の拡散をさまたげ反応を抑制する効果がある といっている。

エンジン油その他の油の摩耗防止剤, 酸化防止剂と してよく使われている化合物にジアルキルジチオリン 酸塩がある。この化合物注造により性能が異なる が，特にバリウム塩は著しい表面活性を有し分散剤， 乳化破壊凨として有効であり ${ }^{9110)}$ ，比較的低分子量の 亜鉛壏は摩耗防止剤として有効だといわれる ${ }^{11}$ 。

種々の型のジチオリン酸塩の四球試験については, $\operatorname{Sanin}^{12113)}$ が発表している。また反応機構について, I. Ming.Feng ${ }^{14)}$, Sanin ${ }^{13)}$ が見解を発表している。

摩耗防止剂として最近固体潤滑剤が注目されてい る。代表的なものは黒鉛, 二硫化モリブデンさらにヨ ウ化カドミウム，塩化カドミウム，ヨウ化鉛などがあ る。これらはいずれも畨状構造の結晶構造を有し（第 11図）各層間です心゙りやすいので摩擦係数が低い。固 体潤滑剂については文献 ${ }^{18)}$ を参照されたい。

\section{V.サビ止メ添加剤19)}

サビ止メ添加剂はサビ止メ剂に多く使用されるほ か，一般工業用潤滑剂に少ビ止入性を与えるためにも
多く使われている。

サビは貯蔵中，輸送中またはシャットダウン中の機 械部品の鉄部分に多く発生する。直留鉱油は若干の严 ビ止メ性をもつているが, さらに過酷な条件では不十 分である。永久的に少ビを止めるには，メッキ,ペイ ントを塗つて表面を保護し，また合金とするなどの方 法がある。しかし一時的にある期間少ビ止入をしてお いて, 工作するとか, 便用するとか, 必要のあるとき にはすぐにとり除けることが必要である。この場合に 使われるのが石油系サビ止入剂である。

サビは水, 酸素その他の腐食性物質が金属表面に接 触することから起る。したがつてサビを防ぐには，金 属表面からこれをさえぎればよい。サビ止入剂は金属 表面に強力な吸着膜を作り, サビの誘因となる物質が 金属に近ずこうとするときの障壁となるとか，金属表 面から除去できるものである。昔は步ビを防止するた めに, 潤滑油, ペトロラタム, グリースなどを塗布し たが，これらは案外によく水や酸素を溶解または浸透 させるので，ほとんでサビ止メ性がない。ところが鉱 油に金属に対する吸着力の強、極性有機化合物を添加 すると，これらの化合物が金属一油界面に吸着して吸 着層を作り，水と金属との接触を防止してサビ止入性 を発揮する。

サビ止メ添加剤として有効な条件としてはつぎのよ うなことがある。

（i）大きな分子に強い極性基のついた化合物 で，これらは双極子能率が大きいので吸着されやす い。たとえば石油スルホン酸塩, Di Iorol phosphate $\left(\begin{array}{l}\mathrm{R}-\mathrm{O} \\ \mathrm{R}-\mathrm{O}\end{array}\right\rangle \mathrm{P}\left\langle\begin{array}{l}\mathrm{O} \\ \mathrm{OH}\end{array}\right)$ がある。

（ii）吸着の程度の弱い極性基を 2 個以上もつた化 合物。

たとえば

$\alpha$-mercapto stearic acid<smiles>[R]C(S)C(=O)O</smiles>

$\alpha$-(2-carboxy phenoxy) stearic acid.<smiles>[R]C(OC1CCCCC1)C(=O)O</smiles> 
Sorbitan mono oleate<smiles>[R]C(=O)C1OCC(O)C(O)C1Cl</smiles>

弱い極性基たとえば $\mathrm{R}-\mathrm{COOH}, \mathrm{R}-\mathrm{OH} ， \mathrm{R}$ $\mathrm{NH}_{2}, \mathrm{R}-\mathrm{C} \equiv \mathrm{N}, \stackrel{\mathrm{O}}{\mathrm{O}-\mathrm{NH}_{2}}$ などを 1 個有する化合 物はサビ止メ性は弱いといわれる。

特殊な例として気相サビ止メ添加剤があるが，シク ロヘキシルアミン亜硝酸塩がよくしられている。これ は精密機械部品のサビ止メや機械輸送の際, 荷造り材 料，包装紙に気相サビ止メ剂をしみ込ませたり，箱の 一隅においたりして使用する。

油が酸化して腐食性の酸を生成し, サビの原因とな ることがある。この場合には酸を中和するために，ア ミン系の化合物を使用する。

サビ止メ添加剂の効果は添加剂と金属との間の極性 基の強さ, 生成した単分子層の性質, 温度条件, 基油 の性質などの因子によるので，使用する際の特殊条件 に合わせてサビ止メ添加剤, 基材を選定することに製 造の難しさがある。

\section{VI. 粘着性向上剂}

ある潤滑条件で金属面に対する潤滑剤の粘着性を向 上する必要があることがある。たとえば遠心力の大き い霜車，軸受などに対するギヤー油，グリースは粘着 性が必要である。粘着性向上凨としては非常に高分子 の重合物たとえばポリイソブチレン，ある種の金属セ ッケンたとえばアルミニウムセッケンなどが使われ る。

しかし，この場合も粘度指数向上剂と同様にせん断
によつて分子が破壊され，低分子量の重合物に変化し 効果を失ならことがある。

\section{文献}

1) Bowden, Taber: The Friction and Lubrication of Soild, Oxford press, 1954

2) Hardy: Collected works, Cambridge University Press, 1936

3) Bowden: 第 3 回世界石油会議

4) Rebinder: Nature, 159, 866 (1947)

5) Epifanov: Doklademii Nauk S.S.S.R. 97, 277 (1954); Lub. Eng., 14, 27 (1958)

6）長野光彦：機械の研究，5，430 (1953)

7) Smalpeer: J. Inst. Petrol., 42, 337 (1956)

8) Barcroft: Wear, 3, 440 (1960)

9) Sanin: Dokl. Akad. Nauk. SSSR, 140, 176 (1961)

10) Vipper: Khimiya i Tekhnologuiya Topliv i Masel No.3, 45 (1958)

11) Sanin: Trudy Nauchno-Tekhnicheskogo Soveshchaniya, Moscow, (1961), p. 26

12) Sanin: Wear, 3, 200 (1960)

13) Sanin: 第 5 回世界石油会議 Section VI - Paper 27 (1964)

14) I. Ming-Feng: Wear, 3, 309 (1960)

15) Cincinati Milling Machine Co. Specification

16) Am. Machinalist, 107, 4102 (1963)

17) Marchant: Lub. Engineering, June 56 (1946)

18）日刊工業：軸受，潤滑便覧，p.575

19) 鹿島 実 : 油化学, 10, 48 (1961); 油化学. 6, 1, (1957)

20) Simard: Ind. Eng. Chem, 33, 1352 (1941): Davey, ibid, 42, 1837 (1950)

21）日刊工業：軸受潤滑便覧，p. 581

\title{
Additives for Industrial Lubricants
}

\author{
by Mitsuhiko Nagano \\ (Central Technical Research Laboratory, Nippon Oil Co.)
}

SYNOPSIS :-This paper outlines the current information of additives entering into formulation of industrial lubricants excluding engine oils. The additives mentioned here are oiliness improver, extreme pressure additive, antiwear agent, antirust agent and cohesive improver. The useful chemicals, function and application of each additive are described. 